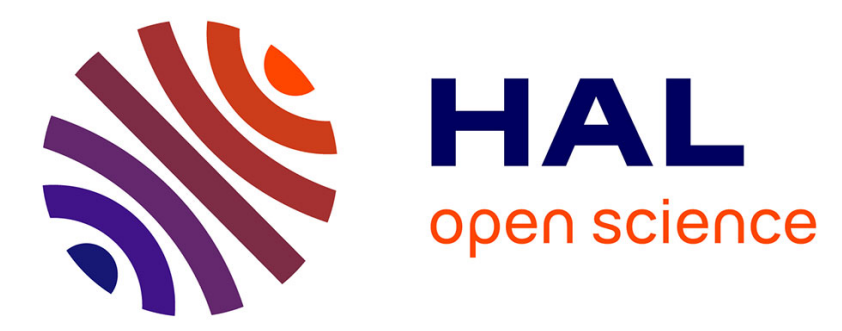

\title{
Top-down and bottom-up control of litter decomposers in streams
}

\author{
Ana Lúcia Gonçalves, Eric Chauvet, Felix Bärlocher, Manuel A. S. Graça, \\ Cristina Canhoto
}

\section{- To cite this version:}

Ana Lúcia Gonçalves, Eric Chauvet, Felix Bärlocher, Manuel A. S. Graça, Cristina Canhoto. Topdown and bottom-up control of litter decomposers in streams. Freshwater Biology, 2014, vol. 59 (n ${ }^{\circ}$ 10), pp. 2172-2182. 10.1111/FWB.12420 . hal-01142618

\section{HAL Id: hal-01142618 \\ https://hal.science/hal-01142618}

Submitted on 15 Apr 2015

HAL is a multi-disciplinary open access archive for the deposit and dissemination of scientific research documents, whether they are published or not. The documents may come from teaching and research institutions in France or abroad, or from public or private research centers.
L'archive ouverte pluridisciplinaire HAL, est destinée au dépôt et à la diffusion de documents scientifiques de niveau recherche, publiés ou non, émanant des établissements d'enseignement et de recherche français ou étrangers, des laboratoires publics ou privés. 


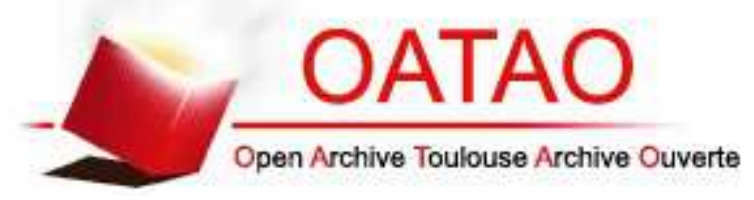

\section{Open Archive TOULOUSE Archive Ouverte (OATAO)}

OATAO is an open access repository that collects the work of Toulouse researchers and makes it freely available over the web where possible.

This is an author-deposited version published in : http://oatao.univ-toulouse.fr/ Eprints ID : 13697

To link to this article : DOI:10.1111/FWB.12420

URL : http://dx.doi.org/10.1111/fwb.12420

To cite this version : Gonçalves, Ana Lúcia and Chauvet, Eric and Bärlocher, Felix and Graça, Manuel A. S. and Canhoto, Cristina Topdown and bottom-up control of litter decomposers in streams. (2014) Freshwater Biology, vol. 59 ( ${ }^{\circ}$ 10). pp. 2172-2182. ISSN 0046-5070

Any correspondance concerning this service should be sent to the repository administrator: staff-oatao@ listes-diff.inp-toulouse.fr 


\title{
Top-down and bottom-up control of litter decomposers in streams
}

\author{
ANA LÚCIA GONÇALVES*, ERIC CHAUVET ${ }^{+} \ddagger$, FELIX BÄRLOCHER ${ }^{\S}$, MANUEL A. S. GRAÇA* AND \\ CRISTINA CANHOTO* \\ *IMAR-CMA, Department of Life Sciences, University of Coimbra, Coimbra, Portugal \\ ${ }^{\dagger}$ INP, UPS, EcoLab (Laboratoire Ecologie Fonctionnelle et Environnement), Université de Toulouse, Toulouse, France \\ ${ }^{\ddagger}$ EcoLab, CNRS, Toulouse, France \\ ${ }^{\S}$ Department of Biology, Mt. Allison University, Sackville, NB, Canada
}

\section{SUMMARY}

1. Detritivores preferentially consume certain aquatic hyphomycete species while rejecting others. Fungal identity may therefore be a crucial factor determining stream food-web structure and complexity and extend the impact of microbial diversity to effects up through the food web. 2. In this study, we examined if shredder feeding is affected by the identity of fungi on leaves (bottom-up effects) and if preferences of shredders for particular fungi affect the composition of fungal assemblages (top-down effects). Oak leaf discs were conditioned in microcosms with six individual fungal species previously reported as highly palatable (P), unpalatable/rejected (R) and intermediate (I). Additionally, three microcosms were inoculated with three mixtures of four fungal species, each consisting of a different subset of the six species.

3. Colonised discs were offered to three detritivores with different feeding strategies: Proasellus sp. (Isopoda), Echinogammarus meridionalis (Amphipoda) and Schizopelex festiva (Trichoptera). When offered leaves colonised by single fungal species, consumption rates by E. meridionalis and S. festiva were higher on I, followed by P and, finally, R species. Consumption rates by Proasellus sp. were similar across fungal treatments. Consumption rates by the three invertebrates were also similar across all fungal multispecies treatments, suggesting that invertebrate preferences for, or rejection of, a given fungal species may be masked when it grows in proximity to other fungi. Composition and structure of fungal communities were not significantly affected by the feeding of any of the three invertebrates.

4. Our results suggest that certain combinations of fungal and detritivore species result in unpredictable bottom-up and top-down effects in stream food webs.

Keywords: consumption, diversity, fungi, shredders, species identity

\section{Introduction}

Riparian vegetation is the main provider of energy, primarily in the form of leaves, to food webs in forested streams (Abelho, 2001; Bärlocher, 2005). In headwaters, leaves are efficiently retained and converted to living biomass by microbes and leaf-shredding detritivores (Abelho, 2001; Gessner et al., 2007; Krauss et al., 2011). Aquatic hyphomycetes are a key group of leaf decomposers and an important trophic link between leaf litter and its animal consumers; fungal colonisation increases the palatability of leaves to invertebrates by increasing nitrogen concentration and by partial enzymatic digestion of structural leaf polymers (Bärlocher \& Porter, 1986; Duarte et al., 2006; Canhoto \& Graça, 2008).

In laboratory experiments, invertebrate shredders often preferentially consume fungal mycelia of certain species (Bärlocher \& Kendrick, 1973a). They also discriminate among leaves or leaf patches colonised by different fungal species (Bärlocher \& Kendrick, 1973b; 
Suberkropp, Arsuffi \& Anderson, 1983; Chung \& Suberkropp, 2009). Feeding preferences may be influenced by several interacting factors such as: (i) leaf traits (Bärlocher \& Kendrick, 1973b) and diversity (Jabiol \& Chauvet, 2012); (ii) invertebrate species and/or feeding guilds (Bärlocher \& Porter, 1986; Arsuffi \& Suberkropp, 1989); (iii) invertebrate size and developmental stage (Chung \& Suberkropp, 2009); (iv) fungal specific traits, including enzyme production, $\mathrm{N}$ content or the presence of attractants or deterrents (Arsuffi \& Suberkropp, 1984; Rong, Sridhar \& Bärlocher, 1995); (v) environmental factors (e.g. stream pH; Dangles \& Chauvet, 2003). To date, no single factor has consistently been linked to palatability of mycelia or fungus-leaf complexes.

The effects of consumption by stream-dwelling detritivores on fungal assemblages have generally been overlooked. However, macroinvertebrates have been shown to reduce sporulation rates and richness of aquatic hyphomycete communities on leaves in streams, primarily by shortening the residence time of the leaves (Bärlocher, 1980). In an insecticide-treated stream, spore numbers were consistently higher than in nearby control streams (i.e. with invertebrates), although the fungal community composition was similar (Suberkropp \& Wallace, 1992). The opposite, that is stimulation of fungal growth and sporulation in the presence of shredders, was observed on recalcitrant substrata (Gonçalves et al., 2007). This has been attributed to ammonium excreted by invertebrates (Villanueva, Albariño \& Canhoto, 2012). Other authors reported no changes in fungal biomass, sporulation rates and community composition in the presence of shredders (Ferreira \& Graça, 2006; Chung \& Suberkropp, 2008).

It remains unclear how the composition of fungal assemblages affects feeding by shredders (bottom-up effect) and how fungal assemblages on leaf litter are in turn affected by macroinvertebrate feeding (top-down effect). Because of the importance of the fungus/invertebrate complex as the main driver of litter processing and energy turnover in streams (Gessner et al., 2007), horizontal (i.e. within trophic levels) and vertical (i.e. between trophic levels) biodiversity effects should be studied concurrently to understand more completely food-web structure and function (Hillebrand \& Matthiesen, 2009; Gessner et al., 2010).

In this study, we investigated whether: (i) the identity of fungal species would affect shredder consumption rates (bottom-up effects) and (ii) the preferences of shredders for particular fungi would affect the composition of the fungal assemblage on leaves (top-down effects). Six fungi were chosen based on earlier studies identifying pairs of palatable (P), unpalatable/rejected (R) and intermediate (I) species. Single and mixed species cultures were used to condition oak leaf discs, which were then offered to three freshwater shredders with different feeding modes: Schizopelex festiva (Sericostomatidae, Trichoptera), a large shredder (high consumer body size:resource ratio), Echinogammarus meridionalis (Amphipoda, Crustacea), a smaller generalist detritivore (low consumer body size:resource ratio), and Proasellus sp. (Isopoda, Crustacea), a litter consumer feeding mainly on leaf surfaces (Graça, Maltby \& Calow, 1993a,b; Feio \& Graça, 2000). Feeding by amphipods has been described as intermediate between that of scrapers and large shredders, given that they rasp and nibble leaves, but with less intensity than other detritivores (Graça et al., 1993a). Some isopods (e.g. Asellus aquaticus) and caddisfly larvae (e.g. Hesperophylax sp. and Limnephilus sp.) with similar feeding strategies have been shown to be selective feeders. They discriminated among patches on the same leaf colonised by different fungal species and consumed them at different rates (Suberkropp et al., 1983; Arsuffi \& Suberkropp, 1986; Graça et al., 1993a).

\section{Methods}

\section{Microcosm settings}

Senescent, freshly fallen leaves of oak (Quercus robur) were collected in autumn near Candal stream (central Portugal) and stored dry. Leaves were cut with a 16mm-diameter cork borer, oven-dried $\left(105^{\circ} \mathrm{C}, 24 \mathrm{~h}\right)$ and weighed individually $( \pm 0.1 \mathrm{mg})$. To reduce variability in initial mass, only discs weighing 10.0-13.9 mg were used. Ten sets of 132 randomly chosen discs were reweighed $( \pm 0.1 \mathrm{mg})$ and placed in individual $500-\mathrm{mL}$ Erlenmeyer flasks with $250 \mathrm{~mL}$ of distilled water and autoclaved. Ten additional sets of ten leaf discs were weighed $( \pm 0.1 \mathrm{mg})$ and placed in test tubes with $25 \mathrm{~mL}$ of distilled water. These discs underwent the same treatment to determine a mass loss correction factor due to leaching during sterilisation.

Autoclaved disc sets were transferred to sterilised 1-L glass bottles (microcosms) with $500 \mathrm{~mL}$ of nutrient solution $\left(75.5 \mathrm{mg} \quad \mathrm{CaCl}_{2}, 10 \mathrm{mg} \quad \mathrm{MgSO}_{4} .7 \mathrm{H}_{2} \mathrm{O}, 0.5 \mathrm{~g}\right.$ 3-morpholinopropanesulphonic acid (MOPS), $5.5 \mathrm{mg}$ $\mathrm{K}_{2} \mathrm{HPO}_{4}$ and $100 \mathrm{mg} \mathrm{KNO}_{3} \mathrm{~L}^{-1}$ of sterile distilled water; Dang, Chauvet \& Gessner, 2005). Microcosms, closed with cotton bungs, were aerated for $24 \mathrm{~h}$ at $15^{\circ} \mathrm{C}$ through tubing connected to an air pump to allow additional leaching. Contamination was prevented by 
passing the airflow through sterile cotton bungs. The mineral salt solution in each microcosm was replaced after $24 \mathrm{~h}$ and inoculated with a total of 62500 conidia (Treton, Chauvet \& Charcosset, 2004) equally divided among the fungal species making up the fungal assemblages (see below).

Aquatic hyphomycetes were isolated from single conidia in foam or released from submerged leaf litter collected from Candal Stream and from streams in south-western France. The species were ranked as highly palatable (P), unpalatable/rejected (R) or intermediate (I) based on Bärlocher \& Kendrick (1973a,b), Suberkropp et al. (1983), Arsuffi \& Suberkropp (1986), Butler \& Suberkropp (1986), Graça et al. (1993a) and Chung \& Suberkropp (2009) (Table 1). The following species were used: Flagellospora curvula $\left(\mathrm{P}_{1}\right)$ and Tetrachaetum elegans $\left(\mathrm{P}_{2}\right)$, Lemonniera aquatica $\left(\mathrm{R}_{1}\right)$ and Tetracladium marchalianum $\left(\mathrm{R}_{2}\right)$, and Clavariopsis aquatica $\left(\mathrm{I}_{1}\right)$ and Articulospora tetracladia $\left(\mathrm{I}_{2}\right)$ (Table 2 ).

To induce conidial release, small agar plugs cut from 14-day-old pure cultures grown on malt extract agar (20 g MEA L ${ }^{-1}$ distilled water) were placed in Erlenmeyer flasks with $25 \mathrm{~mL}$ of nutrient solution (described above) at $15^{\circ} \mathrm{C}$, on an orbital shaker (100 rpm). Three different mixtures of four species were used (one microcosm per treatment): $P_{1} P_{2} I_{1} I_{2}$ (preferred and intermediate species), $P_{1} P_{2} R_{1} R_{2}$ (preferred and rejected species) and $I_{1} I_{2} R_{1} R_{2}$ (intermediate and rejected species). Additionally, six microcosms were inoculated with individual fungal species $\left(\mathrm{P}_{1}, \mathrm{P}_{2}\right.$, $I_{1}, I_{2}, R_{1}$ and $R_{2}$ ), and one microcosm was kept sterile and used to correct for abiotic mass loss. The microcosms were incubated at $15^{\circ} \mathrm{C}$ and aerated during 2 weeks (for the first $6 \mathrm{~h}$ for periods of $15 \mathrm{~min}$ interspersed by periods of $60 \mathrm{~min}$ in which the conidia were allowed to settle, followed by continuous aeration). The nutrient solution was replaced after $24 \mathrm{~h}$ and then every 2 days. All manipulations were performed aseptically.

After 2 weeks, the 132 leaf discs from each microcosm were harvested. Twenty leaf discs (five sets of four discs) were used for ergosterol extraction, and another 20 discs (five sets of four discs) were used to confirm the presence of fungal species by inducing sporulation, to estimate variability within each microcosm. Seventytwo discs were placed individually on filter paper for 5 $\mathrm{s}$ on each side, weighed and immediately used for the feeding experiment. The remaining 20 discs and the 20 leaf discs for ergosterol determination were individually dried on filter paper for $5 \mathrm{~s}$ on each side and then weighed, frozen at $-20^{\circ} \mathrm{C}$, freeze-dried and individually weighed $( \pm 0.1 \mathrm{mg}$ ) to determine the relationship of wet to dry mass.

\section{Fungal biomass}

Five sets of four leaf discs in each treatment were freeze-dried and used to determine concentration in ergosterol as a measure of fungal biomass (as described in Gessner \& Chauvet, 1993 and Graça, Bärlocher \& Gessner, 2005). Ergosterol was converted to fungal biomass assuming $5.5 \mu \mathrm{g}$ ergosterol per mg fungal dry mass (DM) (Gessner \& Chauvet, 1993). Fungal biomass was expressed in mg per $\mathrm{g}$ leaf DM.

\section{Sporulation of aquatic hyphomycetes}

Five sets of four leaf discs of each treatment were used to measure sporulation of aquatic hyphomycetes after day 14 of conditioning. They were incubated in 100-mL Erlenmeyer flasks with $25 \mathrm{~mL}$ of nutrient solution on a shaker (100 rpm; $15{ }^{\circ} \mathrm{C} ; 48 \mathrm{~h}$ ). Conidial suspensions were preserved with $2 \mathrm{~mL}$ of $37 \%$ formalin. Subsamples were filtered (Millipore SMWP, $5 \mu \mathrm{m}$ pore size, Billerica, MA, U.S.A). Trapped spores were stained with $0.05 \%$ cotton blue in lactic acid (60\%), identified and counted at $200 \times$ (Graça et al., 2005). Sporulation rates were converted to spore volumes using the species-specific conversion factors from Bärlocher \& Schweizer (1983) and to conidial mass by the formula: $\mathrm{M}=-0.058 \times \mathrm{V}^{2}+$ $641 \times \mathrm{V}$, where $\mathrm{M}$ is the conidial mass (ng), and $\mathrm{V}$ is the corresponding conidial volume in $\mu^{3}$ (Baldy et al., 2002).

\section{Invertebrate feeding experiment}

Leaf discs inoculated with each one of the nine combinations of fungal species were individually offered to 12 specimens in separate containers of one of the following invertebrate species collected in streams from Central Portugal: Proasellus sp. (Fail stream; 40³6'24.89"N, 0758'30.83"W; $325 \mathrm{~m}$ asl), Echinogammarus meridionalis (Redinha; 39 $58^{\prime} 43.43^{\prime \prime} \mathrm{N}, 08^{\circ} 34^{\prime} 23.94^{\prime \prime} \mathrm{W} ; 98 \mathrm{~m}$ asl) and

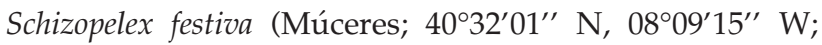
$210 \mathrm{~m}$ asl). Thirty litres of stream water from each stream were filtered (Glass fibre filters; Millipore APFF, $0.7 \mu \mathrm{m}$ pore size) and used in the experiments. Individuals were acclimatised in aerated filtered stream water for 15 days and fed ad libitum with oak litter conditioned in the stream for 2 weeks.

Invertebrates were individually allocated to plastic containers $(70 \mathrm{~mm}$ diameter $\times 85 \mathrm{~mm}$ high $)$ with 
Table 1 Summary of food consumption experiments. The various food sources were offered separately (in separate containers) or together (in one container). Preferences are listed below as rankings

\begin{tabular}{|c|c|c|c|}
\hline Reference & Invertebrate consumer & Measured variable(s) as function of fungal species & Food offered \\
\hline \multirow[t]{2}{*}{ Arsuffi \& Suberkropp, 1986} & Hesperophylax magnus & $\begin{array}{l}\text { Relative consumption rates }\left(\% \mathrm{~d}^{-1}\right) \text { : } \\
\text { 1. Flagellospora curvula } \\
\text { 2. Alatospora acuminata } \\
\text { 3. Tetracladium marchalianum } \\
\text { 4. Lemonniera aquatica }\end{array}$ & Separately \\
\hline & Psychoglypha sp. & $\begin{array}{l}\text { Relative consumption rates }\left(\% \mathrm{~d}^{-1}\right) \text { : } \\
\text { 1. Heliscus lugdunensis } \\
\text { 2. Flagellospora curvula } \\
\text { 3. Alatospora acuminata } \\
\text { 4. Articulospora inflata } \\
\text { 5. Tetracladium marchalianum } \\
\text { 6. Lemonniera aquatica }\end{array}$ & Separately \\
\hline Bärlocher \& Kendrick, 1973a & Gammarus pseudolimnaeus & $\begin{array}{l}\text { Daily consumption of fungal mycelium }\left(\mathrm{mg} \mathrm{d}^{-1}\right) \\
\text { 1. Clavariopsis aquatica } \\
\text { 2. Fusarium sp. } \\
\text { 3. Tricladium angulatum } \\
\text { 4. Anguillospora longissima } \\
\text { 5. Cladosporium sp. } \\
\text { 6. Alternaria sp. } \\
\text { 7. Tetracladium marchalianum } \\
\text { 8. Flagellospora curvula } \\
\text { 9. Aspergillus niger }\end{array}$ & Together \\
\hline Butler \& Suberkropp, 1986 & Psychoglypha sp. & $\begin{array}{l}\text { \% of fungal-colonised leaves consumed: } \\
\text { 1. Flagellospora curvula } \\
\text { 2. Alatospora acuminata } \\
\text { 3. Clavariopsis aquatica } \\
\text { 4. Articulospora inflata } \\
\text { 5. Filosporella annelidica } \\
\text { 6. Tetracladium marchalianum } \\
\text { 7. Lemonniera aquatica } \\
\text { 8. Heliscus lugdunensis }\end{array}$ & Together \\
\hline Chung \& Suberkropp, 2009 & Pycnopsyche gentilis (third instar larvae) & $\begin{array}{l}\text { Degree of shredding (\% loss of patch } \\
\text { area by feeding of fungal patches) } \\
\text { 1. Articulospora tetracladia } \\
\text { 2. Tetrachaetum elegans } \\
\text { 3. Alatospora acuminata } \\
\text { 4. Anguillospora filiformis }\end{array}$ & Together \\
\hline \multirow[t]{2}{*}{ Graça et al., 1993a } & Gammarus pulex & $\begin{array}{l}\text { \% of fungal-colonised leaves consumed: } \\
\text { 1. Anguillospora longissima } \\
\text { 2. Heliscus lugdunensis } \\
\text { 3. Tricladium angulatum } \\
\text { 4. Articulospora tetracladia } \\
\text { 5. Fusarium sp. } \\
\text { 6. Lemonniera aquatica } \\
\text { 7. Tetracladium marchalianum } \\
\text { 8. Cylindrocarpon sp. } \\
\text { 9. Tetracladium setigerum }\end{array}$ & Together \\
\hline & Asellus aquaticus & $\begin{array}{l}\text { \% of fungal-colonised leaves consumed: } \\
\text { 1. Tetracladium marchalianum } \\
\text { 2. Anguillospora longissima } \\
\text { 3. Heliscus lugdunensis } \\
\text { 4. Tetracladium setigerum } \\
\text { 5. Tricladium angulatum } \\
\text { 6. Fusarium sp. } \\
\text { 7. Cylindrocarpon sp. } \\
\text { 8. Articulospora tetracladia } \\
\text { 9. Lemonniera aquatica }\end{array}$ & Together \\
\hline
\end{tabular}


Table 1 (Continued)

\begin{tabular}{|c|c|c|c|}
\hline Reference & Invertebrate consumer & Measured variable(s) as function of fungal species & Food offered \\
\hline \multirow[t]{3}{*}{ Rong et al., 1995} & Gammarus tigrinis & $\begin{array}{l}\text { Daily consumption of fungal-colonised } \\
\text { leaves(mg leaf/mg animal } \mathrm{d}^{-1} \text { ) } \\
\text { 1. Anguillospora filiformis } \\
\text { 2. Clavariopsis aquatica } \\
\text { 3. Tetracladium marchalianum }\end{array}$ & Together \\
\hline & Tipula caloptera & $\begin{array}{l}\text { 1. Anguillospora filiformis } \\
\text { 2. Clavariopsis aquatica } \\
\text { 3. Tetracladium marchalianum }\end{array}$ & Together \\
\hline & Pycnopsyche guttifer & $\begin{array}{l}\text { 1. Anguillospora filiformis } \\
\text { 2. Tetracladium marchalianum } \\
\text { 3. Clavariopsis aquatica }\end{array}$ & Together \\
\hline Suberkropp et al., 1983 & Hesperophylax sp. & $\begin{array}{l}\text { \% of fungal-colonised leaves consumed: } \\
\text { 1. Alatospora acuminata } \\
\text { 2. Flagellospora curvula } \\
\text { 3. Heliscus lugdunensis } \\
\text { 4. Tetracladium marchalianum } \\
\text { 5. Anguillospora pseudolongissima } \\
\text { 6. Clavariopsis aquatica } \\
\text { 7. Tetrachaetum elegans } \\
\text { 8. Articulospora inflata* } \\
\text { 9. Lemonniera aquatica }\end{array}$ & Together \\
\hline
\end{tabular}

*Geniculospora inflata (Ingold) Sv. Nilsson ex Marvanová \& Sv. Nilsson.

Table 2 Palatability list of six fungal taxa according to the literature (see text for detailed citations)

\begin{tabular}{lll}
\hline Fungal species & Palatability & Designations \\
\hline Flagellospora curvula & Highly palatable & $\mathrm{P}_{1}$ \\
Tetrachaetum elegans & Highly palatable & $\mathrm{P}_{2}$ \\
Clavariopsis aquatica & Intermediate palatable & $\mathrm{I}_{1}$ \\
Articulospora tetracladia & Intermediate palatable & $\mathrm{I}_{2}$ \\
Lemonniera aquatica & Unpalatable/rejected & $\mathrm{R}_{1}$ \\
Tetracladium marchalianum & Unpalatable/rejected & $\mathrm{R}_{2}$ \\
\hline
\end{tabular}

$200 \mathrm{~mL}$ of stream water. Aeration was continuously provided with aquarium pumps. The bottom of the containers was covered with a fine layer of ashed $\left(550{ }^{\circ} \mathrm{C}\right.$; $6 \mathrm{~h}$ ) stream sediment from the original stream. Each microcosm was supplied with two leaf discs, one leaf disc was exposed to invertebrate feeding while the other was enclosed in a small fine mesh bag, attached to the edge of each container and used as control. The experiment was run at $15{ }^{\circ} \mathrm{C}$ with a 12 : 12 dark:light photoperiod.

After two (S. festiva) or four days (Proasellus sp. and E. meridionalis), when a mean of $50 \%$ of the exposed disc's surface area remained, the experiment was stopped and the remaining litter mass was recovered. All discs (control and exposed) were frozen at $-20{ }^{\circ} \mathrm{C}$, freeze-dried and weighed $( \pm 0.1 \mathrm{mg})$. Initial DM of leaf discs was determined from the linear regression between wet and dry disc mass (see above). Consumption was calculated as the difference between control and exposed discs in each microcosm. Consumers were removed from each container, dried at $105{ }^{\circ} \mathrm{C}$ for $48 \mathrm{~h}$ and weighed to the nearest $0.1 \mathrm{mg}$. Individual relative consumption rates (RCR) for each leaf treatment were expressed as consumption per mg invertebrate DM per day.

\section{Molecular analysis}

To compare the composition of the fungal assemblage on control discs before exposure to invertebrates and on discs after exposure, the presence and relative contributions to total biomass of individual fungal species were assessed with denaturing gradient gel electrophoresis (DGGE). Band intensities on the gel were estimated by measuring pixel density with ImageJ (http://rsbweb.nih.gov/ij/ by National Institutes of Health).

DNA from four leaf discs from each treatment (control and invertebrate-exposed discs) was extracted with the UltraClean Soil DNA kit (MoBio Laboratories, Solana Beach, CA, U.S.A) according to the manufacturer's instructions, and DNA was pooled to obtain one value per treatment. The ITS2 region of fungal ribosomal DNA was amplified with the primer pair ITS3GC and ITS4 (Nikolcheva \& Bärlocher, 2005). For polymerase chain reaction (PCR), $0.5 \mu \mathrm{L}$ of each primer, $12.5 \mu \mathrm{L}$ of Taq DNA polymerase, $9.5 \mu \mathrm{L}$ of nuclease-free water and 
$2 \mu \mathrm{L}$ of DNA extract were mixed in a final volume of $25 \mu \mathrm{L}$. The amplification programme started with initial denaturation for $2 \mathrm{~min}$ at $95^{\circ} \mathrm{C}$, followed by 36 cycles of denaturation for $30 \mathrm{~s}$ at $95{ }^{\circ} \mathrm{C}$, primer annealing for $30 \mathrm{~s}$ at $55{ }^{\circ} \mathrm{C}$ and extension for $1 \mathrm{~min}$ at $72{ }^{\circ} \mathrm{C}$, ending with a final extension for $5 \mathrm{~min}$ at $72{ }^{\circ} \mathrm{C}$ (Nikolcheva \& Bärlocher, 2005; Eppendorf Mastercycler EP gradient S, New York, NY, U.S.A).

The 380- to 400-bp amplification products of each treatment were analysed with the DCode $\mathrm{C}^{\mathrm{TM}}$ Universal Mutation Detection System (Bio-Rad Laboratories, Hercules, CA, U.S.A). Samples of $20 \mu \mathrm{L}$ PCR products were loaded on $8 \%(\mathrm{w} / \mathrm{v})$ polyacrylamide gels in $1 \times$ TrisAcetate-EDTA (TAE) with a denaturing gradient from 30 to $70 \%$ (100\% denaturant corresponds to $40 \%$ formamide and $7 \mathrm{~m}$ urea). A DNA mixture from pure cultures of the aquatic hyphomycete species (F. curvula, T. elegans, L. aquatica, T. marchalianum, C. aquatica and A. tetracladia) was used to calibrate the DGGE gels. The gels were run in $1 \times \mathrm{TAE}$ at $55 \mathrm{~V}$ for $16 \mathrm{~h}$ at $56{ }^{\circ} \mathrm{C}$ and stained with $1 \times$ gelRed.

\section{Data analysis}

Initial DM of discs was calculated from linear regressions between specific wet/dry mass for each microcosm $\left(R^{2} \geq 0.75\right)$. Mycelial biomass from ergosterol and DNA banding intensity, total conidial mass, as well as relative consumption rate for the three invertebrate species were compared among initial fungal assemblages by one-way ANOVA. Tukey's tests were applied for post hoc multiple comparisons whenever relevant (STATISTICA 7). Data were transformed $(\log (x+1))$ when necessary to satisfy assumptions of normality and homoscedasticity (Zar, 1999).

DGGE banding intensities of fungal assemblages on oak leaf discs before and after invertebrate exposure (control versus exposed leaf disc) were analysed by nonmetric multidimensional scaling (NMDS) ordination for each invertebrate species, based on the Bray-Curtis similarity index of $\log (x+1)$-transformed banding intensities data (PRIMER v6; Clarke \& Gorley, 2001). Analyses of similarity (one-way ANOSIM) and hierarchical clusters were performed among mixed treatments.

\section{Results}

\section{Microbial conditioning}

Mycelial biomass (based on ergosterol) associated with the leaf discs differed significantly among fungal (C) 2014 John Wiley \& Sons Ltd, Freshwater Biology, 59, 2172-2182 treatments (one-way ANOvA, $F_{8,36}=75.40, \quad P<0.001$; Fig. 1), with T. elegans $\left(\mathrm{P}_{2}\right)$ exhibiting the lowest (Tukey's test, $P=0.088$ ) and L. aquatica $\left(\mathrm{R}_{2}\right)$ the highest values (Tukey's test, $P=0.008$ ). In individual cultures, mycelial biomass tended to be lower in microcosms containing leaf discs inoculated with $\mathrm{P}$ than with I and $\mathrm{R}$ species, which also affected the fungal biomass in mixed cultures; when $\mathrm{P}$ species were present in the inoculum, fungal biomass was significantly lower (Tukey's test, $P<0.036$ ). Fungal biomass in mixed cultures was lower than the biomass in three of the six pure cultures (Tukey's test, $P<0.001$ ).

In DGGE gels, the bands obtained from control discs of some fungal species ( F. curvula and T. elegans, $\mathrm{P}_{1} / \mathrm{P}_{2}$, and $A$. tetracladia and L. aquatica, $\mathrm{I}_{1} / \mathrm{R}_{2}$ ) were very close to each other, impairing the ability to differentiate among all species within an assemblage. The abovementioned tendency for lower biomass in monocultures with $\mathrm{P}$, followed by $\mathrm{I}$ and $\mathrm{R}$ species, was also apparent here. However, total fungal biomass of all mixtures tended to be equal or higher than in monocultures (oneway ANOVA, $F_{8,18}=10.26, P<0.001$; Fig. 1 ).

Total conidial mass produced on day 14 was affected by the composition of initial inocula (one-way ANOVA, $F_{8,34}=315.79, P<0.001$; Fig. 2$)$, with F. curvula $\left(\mathrm{P}_{1}\right)$ and C. aquatica $\left(\mathrm{I}_{2}\right)$ exceeding all others. By contrast, T. elegans $\left(\mathrm{P}_{2}\right)$ produced fewer spores in single cultures than in mixed assemblages. The total conidial mass of each species in mixed cultures was generally lower than in

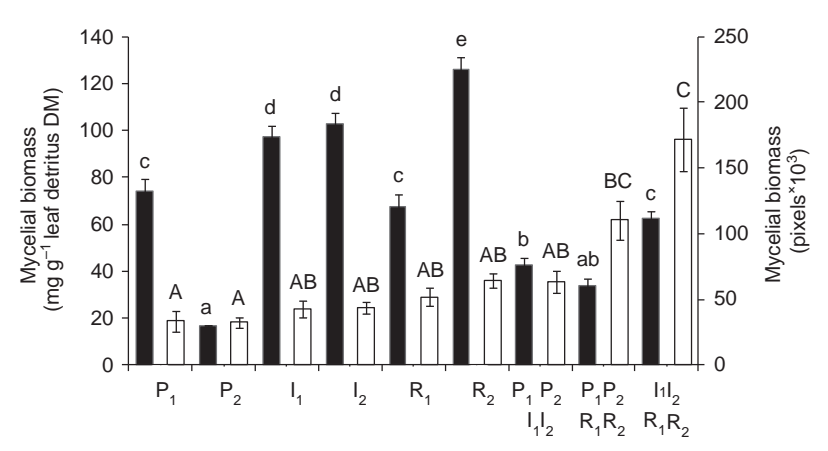

Fig. 1 Mycelial biomass from ergosterol $(\square ; n=5, \pm \mathrm{SE})$ and DNA banding intensity in denaturing gradient gel electrophoresis gels ( $\square ; n=3, \pm$ SE) associated with oak leaf discs in microcosms, incubated with mono- or multicultures of six aquatic hyphomycete species for two weeks. $\mathrm{P}_{1}-$ Flagellospora curvula, $\mathrm{P}_{2}-$ Tetrachaetum elegans, $\mathrm{I}_{1}$ - Clavariopsis aquatica, $\mathrm{I}_{2}$ - Articulospora tetracladia, $\mathrm{R}_{1}-$ Lemonniera aquatica and $\mathrm{R}_{2}$ - Tetracladium marchalianum, where $\mathrm{P}, \mathrm{R}$ and I indicate preferred, rejected and intermediate preference by consumers from literature. Significant differences $(P<0.05)$ among treatments are indicated by different letters (lower-case letters for mycelial biomass, upper-case letters for total fungal biomass). 


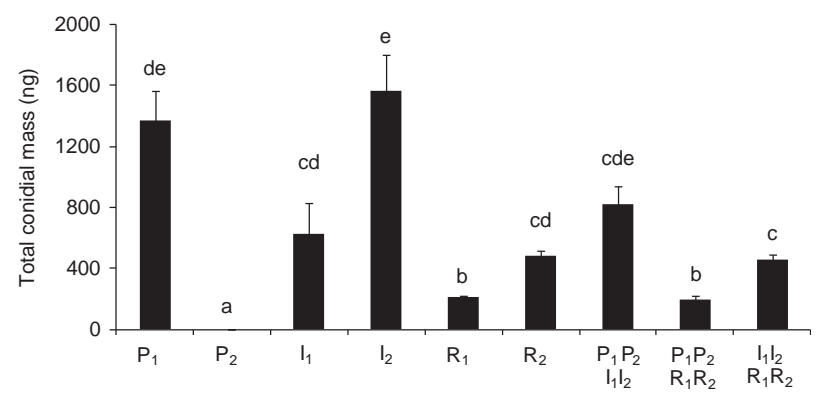

Fig. 2 Total conidial mass from oak leaf discs in microcosm, inoculated with individual and mixtures of six aquatic hyphomycete species for two weeks ( $n=5, \pm \mathrm{SE}$ ). $\mathrm{P}_{1}-$ Flagellospora curvula, $\mathrm{P}_{2}$ - Tetrachaetum elegans, $\mathrm{I}_{1}$ - Clavariopsis aquatica, $\mathrm{I}_{2}$ - Articulospora tetracladia, $\mathrm{R}_{1}$ - Lemonniera aquatica and $\mathrm{R}_{2}$ - Tetracladium marchalianum. Significant differences $(P<0.05)$ of conidial mass among different treatments are indicated by different letters.

monocultures. Clavariopsis aquatica $\left(\mathrm{I}_{2}\right)$ tended to be dominant, while mixed assemblages with $\mathrm{R}$ species tended to be co-dominated by more than one species (data not shown).

\section{Invertebrate feeding}

Proasellus consumption rates were not significantly affected by aquatic hyphomycete assemblages (one-way ANOVA, $\quad F_{8,33}=0.61, P=0.77 ;$ Fig. 3a). Echinogammarus meridionalis consumed more of leaf discs colonised by monocultures of I and $\mathrm{P}$ rather than $\mathrm{R}$ species (one-way ANOvA, $F_{8,31}=16.68, P<0.001$; Fig. $\left.3 b\right)$. No significant differences were detected among consumption rates of discs inoculated by combinations of four species (Tukey's test, $P>0.082$ ). Consumption of these discs ranged from low to intermediate compared with discs inoculated with monocultures.

Finally, consumption by S. festiva was higher from discs with a monoculture of C. aquatica $\left(\mathrm{I}_{2}\right)$ over those with T. elegans $\left(\mathrm{P}_{2}\right)$ (Tukey's test, $P=0.014$; Fig. $3 \mathrm{c}$ ). This shredder had similar consumption rates on leaves colonised by the three fungal assemblages.

\section{Effects of invertebrate feeding activities on fungal assemblages}

Based on DNA band intensities, fungal assemblages in leaf discs were not significantly modified by the feeding activities of any animal species tested (one-way ANOSIM, $R^{2}>0.088, P>0.80$; Fig. $\left.4 \mathrm{a}-\mathrm{c}\right)$. There was more than $80 \%$ similarity between fungal assemblages on control discs and those exposed to invertebrates.
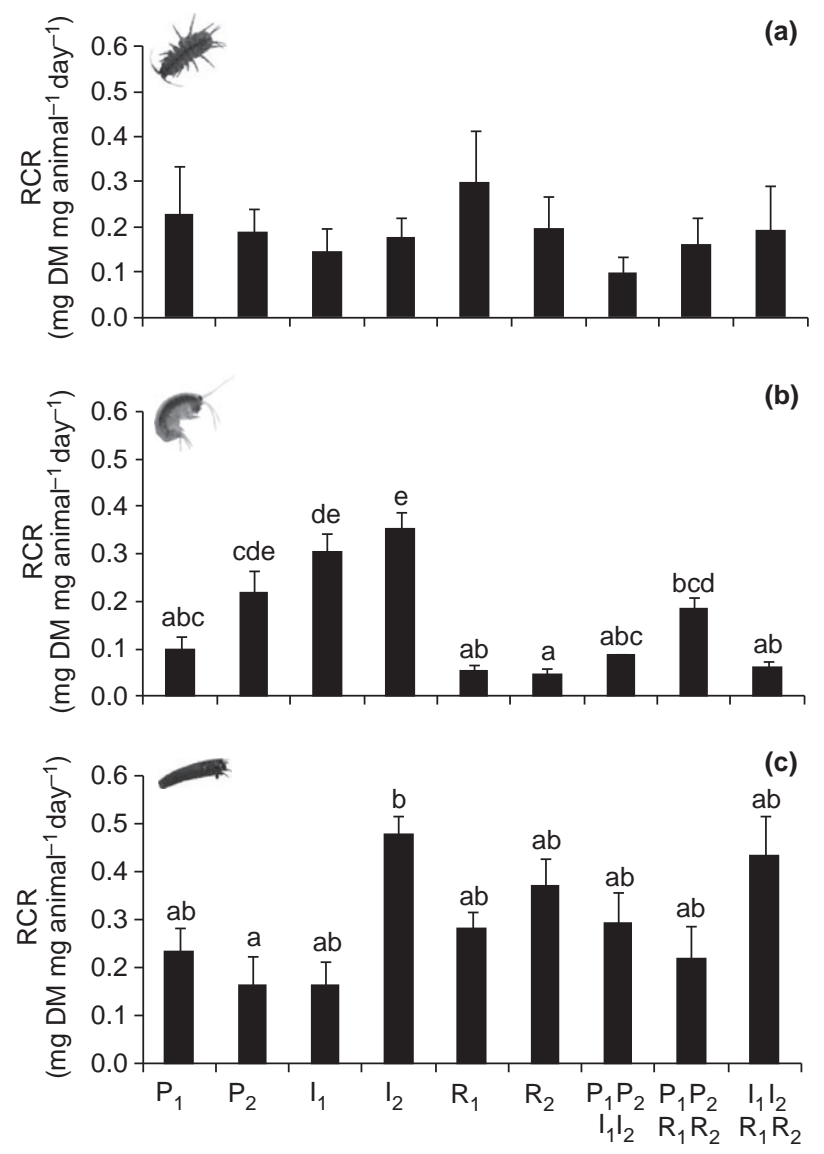

Fig. 3 Relative consumption rates (RCR) of (a) Proasellus sp. (b) E. meridionalis and (c) S. festiva fed oak leaf discs conditioned with individual and mixtures of the six aquatic hyphomycete species ( $n=12, \pm \mathrm{SE}) . \mathrm{P}_{1}-$ Flagellospora curvula, $\mathrm{P}_{2}-$ Tetrachaetum elegans, $\mathrm{I}_{1}$ - Clavariopsis aquatica, $\mathrm{I}_{2}$ - Articulospora tetracladia, $\mathrm{R}_{1}$ - Lemonniera aquatica and $\mathrm{R}_{2}$ - Tetracladium marchalianum. Significant differences $(P<0.05)$ of mycelial biomass among different treatments are indicated by different letters.

\section{Discussion}

When discs colonised by single fungal species were offered in individual microcosms, the consumption rate of two of the invertebrates (E. meridionalis and S. festiva) differed with fungal species, suggesting selective feeding. Earlier studies suggested that both F. curvula and T. elegans should be of high, and C. aquatica, of intermediate palatability (Bärlocher \& Kendrick, 1973a,b; Suberkropp et al., 1983; Arsuffi \& Suberkropp, 1986; Butler \& Suberkropp, 1986; Chung \& Suberkropp, 2009). However, these three fungi were not favoured by Proasellus or E. meridionalis, suggesting that the invertebrate preferences for fungal species are species-specific. By contrast, all invertebrates consumed statistically identical amounts 

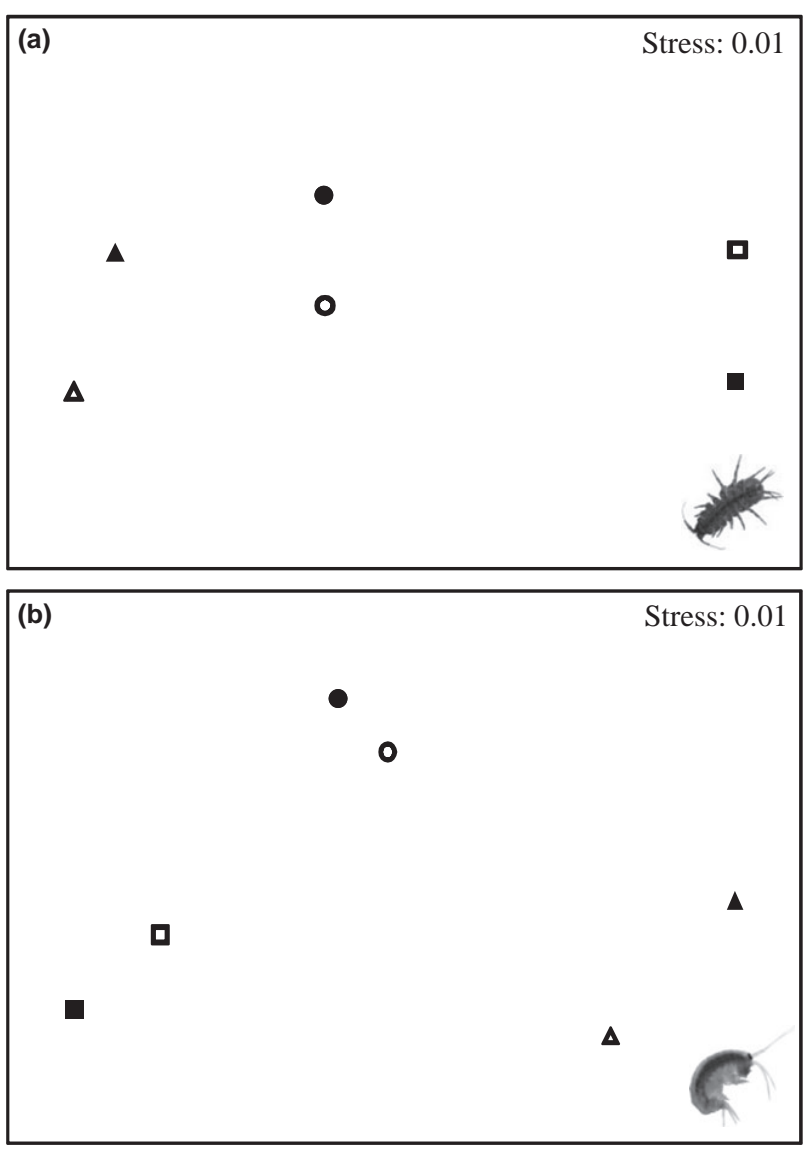

(c)

Stress: 0.01

$\Delta$

口

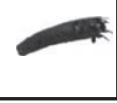

Fig. 4 Ordination (non-metric multidimensional scaling) of mixed fungal assemblages in oak leaf discs before and after invertebrate exposure (control versus exposed leaf disc) to (a) Proasellus sp. (b) Echinogammarus meridionalis and (c) Schizopelex festiva, based on Bray-Curtis similarity matrix of fungal DNA banding. $\Delta-\mathrm{P}_{1} \mathrm{P}_{2} \mathrm{I}_{1} \mathrm{I}_{2}$ control; $\triangle-\mathrm{P}_{1} \mathrm{P}_{2} \mathrm{I}_{1} \mathrm{I}_{2}$ exposed; $\square-\mathrm{P}_{1} \mathrm{P}_{2} \mathrm{R}_{1} \mathrm{R}_{2}$ control; $\square-\mathrm{P}_{1} \mathrm{P}_{2} \mathrm{R}_{1} \mathrm{R}_{2}$ exposed; - $\mathrm{I}_{1} \mathrm{I}_{2} \mathrm{R}_{1} \mathrm{R}_{2}$ control; o- $\mathrm{I}_{1} \mathrm{I}_{2} \mathrm{R}_{1} \mathrm{R}_{2}$ exposed.

of leaf material colonised by the three combinations of four fungi. In all three invertebrates, consumption tended to be higher on one or more of the single-culture discs than on any of the mixed-culture discs (although the difference was not significant with Proasellus sp.). Thus, invertebrate preference or rejection of a given fungal species may be masked when it grows in mixtures with other fungi. This may have implications for fungal growth - depending on the identity of neighbouring colonies, some intermingling with non-related mycelia may be beneficial, rather than an interference.

Non-preferential feeding was also reported in Pycnopsyche gentilis (Trichoptera): consumption of leaf patches colonised by different fungal species did not differ significantly (Chung \& Suberkropp, 2009). Other studies, however, showed that isopods (e.g. Asellus aquaticus), amphipods (e.g. Gammarus pseudolimnaeus and Gammarus pulex) and caddisfly larvae (e.g. Hesperophylax sp. and Limnephilus sp.) detected and discriminated among fungal species offered as mycelium or growing on various leaf species (Bärlocher \& Kendrick, 1973a; Suberkropp et al., 1983; Arsuffi \& Suberkropp, 1986; Graça et al., 1993a). This discrepancy may be related to the fact that, in previous studies, different fungal species occurred on well-separated leaf patches and their hyphae did not intermingle (Bärlocher \& Kendrick, 1973a,b; Suberkropp et al., 1983; Arsuffi \& Suberkropp, 1986; but see Chung \& Suberkropp, 2009). In our study, we simultaneously inoculated four fungal species onto leaf discs, presumably allowing intimate mixing. This may present a more realistic scenario, since up to 12 species can be found on a single leaf in the field (Shearer \& Lane, 1983). On the other hand, the design of our experiments did not give the consumer a true choice among food items within the same microcosm, which may accentuate differential feeding (Table 1).

Colonisation patterns by individual fungal species in mixed inocula strongly depend on the identity of co-colonisers, with direct repercussions on growth patterns and reproductive output (Bärlocher, 1991; Yuen, Hyde \& Hodgkiss, 1999; Ferreira et al., 2010). In the current study, mycelial biomass (based as ergosterol) and species-specific conidial production in mixtures were generally lower than in the respective monocultures, suggesting some degree of mutual inhibition (Pascoal et al., 2010). The intensities of DGGE bands of amplified fungal DNA confirmed the presence of the appropriate species, even when spore production was minimal (T. elegans). However, fungal biomass estimated by DGGE band densities diverged from biomass estimated by ergosterol (Fig. 1). This is not unexpected since ergosterol concentrations of fungal mycelia can vary by a factor of up to 14, depending on species and culture conditions (Charcosset \& Chauvet, 2001) and DNA 
content strongly depends on fungal age (Grimmett et al., 2013). This illustrates the need for new and more discriminatory quantitative approaches, such as quantitative real-time or in situ PCR, to overcome the current difficulty of assessing the relative abundances of fungal species and their spatial distribution within leaves or leaf patches (Krauss et al., 2011).

It is generally accepted that the relationships between invertebrates and fungal assemblages are affected not only by the identity of fungal species but also by the substratum quality, with fungal conditioning becoming more important on recalcitrant leaves (Jabiol \& Chauvet, 2012). We therefore expected clear feeding preferences in our experiments with oak leaves. While this was the case with discs inoculated with single fungal species, there was no selective feeding on discs with several species, suggesting that all fungal assemblages guaranteed a level of conditioning sufficient to stimulate shredder consumption (either to acquire the resources, i.e. leaf and fungi, or simply to acquire enzymatic activity), independently of the species involved. Several previous studies have also failed to relate consistently palatability of a fungus-leaf combination to selected parameters, such as lipids, proteins, fungal biomass or activities of various degradative enzymes (e.g. Arsuffi \& Suberkropp, 1985). Rong et al. (1995) suggested that a combination of nutritional improvements due to fungal colonisation (macronutrients such as proteins, lipids, carbohydrates, as well as leaching or possibly fungal inactivation of leaf toxins) is important in food choice. Once these changes have reached a threshold, more specific repellents and attractants, or possibly micronutrients, may fine-tune the feeding preferences of invertebrates. A further complication is the fact that even minor changes in incubation temperature or nutrient concentration in the medium can drastically affect palatability and nutritional value of fungal mycelia (Nikolei, 1961).

The presence of species that were preferred when offered as monocultures did not consistently influence the feeding activity of the three shredders on leaves with mixed cultures. This suggests that the invertebrates (despite their distinct feeding modes) were unable to discriminate among species grown in mixtures and/or that fungal assemblages have common emergent properties that compensate for the inherent variability of individual fungal species (e.g. composition, stoichiometry). It has been suggested that shredders have different physiological and behavioural adaptations that compensate for stoichiometrical imbalances between food and consumers (essentially C: N ratios; Tuchman et al., 2003; Canhoto \& Graça, 2008). However, the actual impact of invertebrate feeding on fungal biomass and assemblages was assumed to depend on the characteristics and number of the species involved (e.g. composition, physiological condition and efficiency of the digestive process; Cross et al., 2005).

Different modes of feeding can shift the composition of the fungal assemblage by selectively removing some mycelia and ignoring others, and $S$. festiva did induce some shifts in the quantity of DNA of the $I_{1} I_{2} R_{1} R_{2}$ treatment. However, we did not observe any significant changes in the fungal assemblages of control and invertebrate-exposed discs. In our experiments, we had a maximum of four fungal species, whose biomasses were fairly evenly distributed, and both control and treatment discs were examined after identical incubation periods. This prevented us from observing all potential effects of top-down control by invertebrates that might occur in the field, such as the occurrence of late arrivals on discs inaccessible to invertebrates. In addition, invertebrates only had access to one food source at a time, disallowing actual choices between fungus/leaf combinations, which might have influenced overall species distribution in the entire system. Our design also ignored the potential impact of faster decomposition (reduced residence time) often observed in the presence of invertebrates (Chung \& Suberkropp, 2008). Based on the 'more individuals hypothesis' (Evans, Greenwood \& Gaston, 2005), we would expect greater overall fungal diversity on leaves whose breakdown is delayed, as might happen in the absence of shredding invertebrates.

The general absence of top-down effects of invertebrates on fungi was unexpected, in view of previously reported strong preferences among patches (or leaf discs) colonised by different fungal species (e.g. Bärlocher \& Kendrick, 1973a,b; Suberkropp et al., 1983; Arsuffi \& Suberkropp, 1986; Graça et al., 1993a; Jabiol \& Chauvet, 2012). This suggests that certain combinations of fungi and detritivores result in unpredictable bottomup and top-down effects in stream food webs.

\section{Acknowledgments}

We thank Ana Virgínia Lírio for the assistance in the field and laboratory experience, and Ivan Grimmett with help in molecular techniques in Mount Allison University (supported by an NSERC Canada grant to FB). Financial support by the Portuguese Science and Technology Foundation (reference SFRH/BD/47089/2008) to ALG is gratefully acknowledged. This study was supported by the European Regional Development Fund (ERDF) through the COMPETE - Operational Factors of 
Competitiveness Program (POFC-COMPETE) and national funds through FCT - Foundation for Science and Technology, under the project 'Predicting the effect of global warming on stream ecosystems' (FCT Ref: PTDC/CLI/67180/2006; COMPETE Ref: FCOMP-010124-FEDER-007112) and by the Pessoa exchange programme between Portugal and France (PHC 22808 TB) from the French Ministry of Foreign and European Affairs.

\section{Declaration of authorship}

All authors conceived and designed the experiments. ALG performed the experiments and wrote the first draft of the manuscript, and all authors collaborated on writing the final version.

\section{References}

Abelho M. (2001) From litterfall to breakdown in streams: a review. The Scientific World, 1, 656-680.

Arsuffi T.L. \& Suberkropp K. (1984) Leaf processing capabilities of aquatic hyphomycetes: interspecific differences and influence on shredder feeding preferences. Oikos, 42, 144-454.

Arsuffi T.L. \& Suberkropp K. (1985) Selective feeding by stream caddisfly (Trichoptera) detritivores on leaves with fungal-colonized patches. Oikos, 45, 50-58.

Arsuffi T.L. \& Suberkropp K. (1986) Growth of two stream caddisflies (Trichoptera) on leaves colonized by different fungal species. Journal of the North American Benthological Society, 5, 297-305.

Arsuffi T.L. \& Suberkropp K. (1989) Selective feeding by shredders on leaf-colonising stream fungi: comparison of macroinvertebrate taxa. Oecologia, 79, 30-37.

Baldy V., Chauvet E., Charcosset J.Y. \& Gessner M.O. (2002) Microbial dynamics associated with leaves decomposing in the main stem and floodplain pond of a large river. Aquatic Microbial Ecology, 28, 25-36.

Bärlocher F. (1980) Leaf-eating invertebrates as competitors of aquatic hyphomycetes. Oecologia, 47, 303-306.

Bärlocher F. (1991) Intraspecific hyphal interactions among aquatic hyphomycetes. Mycologia, 83, 82-88.

Bärlocher F. (2005) Freshwater fungal communities. In: The Fungal Community: Its Organization and Role in the Ecosystem (Eds J. Deighton, J.F. White Jr \& P. Oudemans), pp. 39-60. Taylor and Francis, CRC Press, Boca Raton.

Bärlocher F. \& Kendrick B. (1973a) Fungi and food preferences of Gammarus pseudolimnaeus. Archiv für Hydrobiologie, 72, 501-516.

Bärlocher F. \& Kendrick B. (1973b) Fungi in the diet of Gammarus pseudolimnaeus (Amphipoda). Oikos, 24, 295-300.
Bärlocher F. \& Porter C.W. (1986) Digestive enzymes and feeding strategies of three stream invertebrates. Journal of the North American Benthological Society, 5, 58-66.

Bärlocher F. \& Schweizer M. (1983) Effects of leaf size and decay rate on colonization by aquatic hyphomycetes. Oikos, 41, 205-210.

Butler S.K. \& Suberkropp K. (1986) Aquatic hyphomycetes on oak leaves: comparison of growth, degradation and palatability. Mycologia, 78, 922-928.

Canhoto C. \& Graça M.A.S. (2008) Interactions between fungi and stream invertebrates: back to the future. In: Novel Techniques and Ideas in Mycology (Eds S. Sridhar, F. Bärlocher \& K.D. Hyde), pp. 305-325. University Press, Hong Kong.

Charcosset J.-Y. \& Chauvet E. (2001) Effect of culture conditions on ergosterol as an indicator of biomass in the aquatic hyphomycetes. Applied and Environmental Microbiology, 67, 2051-2055.

Chung N. \& Suberkropp K. (2008) Influence of shredder feeding and nutrients on fungal activity and community structure in headwater streams. Fundamental and Applied Limnology, 173, 35-46.

Chung N. \& Suberkropp K. (2009) Effects of aquatic fungi on feeding preferences and bioenergetics of Pycnopsyche gentilis (Trichoptera: Limnephilidae). Hydrobiologia, 630, 257-269.

Clarke K.R. \& Gorley R.N. (2001) Primer v5: User Manual/ Tutorial. Primer-E Ltd, Plymouth, UK.

Cross W.R., Benstead J.P., Frost P.C. \& Thomas S.A. (2005) Ecological stoichiometry in freshwater benthic systems: recent progress and perspectives. Freshwater Biology, 50, 1895-1912.

Dang C.K., Chauvet E. \& Gessner M.O. (2005) Magnitude and variability of process rates in fungal diversity-litter decomposition relationships. Ecology Letters, 8, 1129-1137.

Dangles O. \& Chauvet E. (2003) Effects of stream acidification on fungal biomass in decaying beech leaves and leaf palatability. Water Research, 37, 533-538.

Duarte S., Pascoal C., Cássio F. \& Bärlocher F. (2006) Aquatic hyphomycete diversity and identity affect leaf litter decomposition in microcosms. Oecologia, 147, 658-666.

Evans K.L., Greenwood J.J.D. \& Gaston K.J. (2005) Dissecting the species-energy relationship. Proceedings of the Royal Society of London-Series B, 272, 2155-2163.

Feio M.J. \& Graça M.A.S. (2000) Food consumption by the larvae of Sericostoma vittatum (Trichoptera), an endemic species from the Iberian Peninsula. Hydrobiologia, 439, 7-11.

Ferreira V., Gonçalves A.L., Pratas J. \& Canhoto C. (2010) Contamination by uranium mine drainages may affect fungal growth and interactions between fungal species and strains. Mycologia, 102, 1004-1011.

Ferreira V. \& Graça M.A.S. (2006) Do invertebrate activity and current velocity affect fungal assemblage structure in leaves? International Review of Hydrobiology, 91, 1-14. 
Gessner M.O. \& Chauvet E. (1993) Ergosterol-to-biomass conversion factors for aquatic hyphomycetes. Applied and Environmental Microbiology, 59, 502-507.

Gessner M.O., Gulis V., Kuehn K.A., Chauvet E. \& Suberkropp K. (2007) Fungal decomposers of plant litter in aquatic ecosystems. In: The Mycota, Volume IV: Microbial and Environmental Relationships (2nd edn) (Eds C.P. Kubicek \& I.S. Druzhinina), pp. 301-324. Springer, Berlin.

Gessner M.O., Swan C.M., Dang C.K., McKie B.G., Bardgett R.D., Wall D.H. et al. (2010) Diversity meets decomposition. Trends in Ecology \& Evolution, 25, 372-380.

Gonçalves A.L., Gama A.M., Ferreira V., Graça M.A.S. \& Canhoto C. (2007) The breakdown of Blue Gum (Eucalyptus globulus Labill.) bark in a Portuguese stream. Fundamental and Applied Limnology, 168, 307-315.

Graça M.A.S., Bärlocher F. \& Gessner M.O. (2005) Methods to Study Litter Decomposition. A Practical Guide, Springer, The Netherlands.

Graça M.A.S., Maltby L. \& Calow P. (1993a) Importance of fungi in the diet of Gammarus pulex (L.) and Asellus aquaticus (L.) I. Feeding strategies. Oecologia, 93, 139-144.

Graça M.A.S., Maltby L. \& Calow P. (1993b) Importance of fungi in the diet of Gammarus pulex and Asellus aquaticus. II. Effects on growth, reproduction and physiology. Oecologia, 96, 304-309.

Grimmett I.J., Shipp K.N., MacNeil A. \& Bärlocher F. (2013) Does the growth rate hypothesis apply to aquatic hyphomycetes? Fungal Ecology, 6, 493-500.

Hillebrand H. \& Matthiesen B. (2009) Biodiversity in a complex world: consolidation and progress in functional biodiversity research. Ecology Letters, 12, 1405-1419.

Jabiol J. \& Chauvet E. (2012) Fungi are involved in the effects of litter mixtures on consumption by shredders. Freshwater Biology, 57, 1667-1677.

Krauss G.J., Solé M., Krauss G., Schlosser D., Wesenberg D. \& Bärlocher F. (2011) Fungi in freshwaters: ecology, physiology and biochemical potential. FEMS Microbiology Ecology, 35, 620-651.

Nikolcheva L.G. \& Bärlocher F. (2005) Seasonal and substrate preferences of fungi colonizing leaves in streams: traditional versus molecular evidence. Environmental Microbiology, 7, 270-280.
Nikolei E. (1961) Vergleichende Untersuchungen zur Fortpflanzung heterogener Gallmücken under experimentellen Bedingungen. Zeitschrift für Morphologie und Ökologie der Tiere, 50, 281-329.

Pascoal C., Cássio F., Nikolcheva L.G. \& Bärlocher F. (2010) Realized fungal diversity increases functional stability of leaf-litter decomposition under zinc stress. Microbial Ecology, 59, 84-93.

Rong Q., Sridhar K.R. \& Bärlocher F. (1995) Food selection in three leaf-shredding stream invertebrates. Hydrobiologia, 316, 173-181.

Shearer C.A. \& Lane L.C. (1983) Comparison of three techniques for the study of aquatic hyphomycete communities. Mycologia, 75, 498-508.

Suberkropp K., Arsuffi T.L. \& Anderson J.P. (1983) Comparison of degradative ability, enzymatic activity, and palatability of aquatic hyphomycetes grown on leaf litter. Applied and Environmental Microbiology, 46, 237-244.

Suberkropp K. \& Wallace J.B. (1992) Aquatic hyphomycetes in insecticide-treated and untreated streams. Journal of the North American Benthological Society, 11, 165-171.

Treton C., Chauvet E. \& Charcosset J.Y. (2004) Competitive interaction between two aquatic hyphomycete species and increase in leaf litter breakdown. Microbial Ecology, 48, 439-446.

Tuchman N.C., Wahtera K.A., Wetzel R.G., Russo N.M., Kilbane G.M., Sasso L.M. et al. (2003) Nutritional quality of leaf detritus altered by elevated atmospheric $\mathrm{CO}_{2}$ : effects on development of mosquito larvae. Freshwater Biology, 48, 1432-1439.

Villanueva V.D., Albariño R. \& Canhoto C. (2012) Positive effect of shredders on microbial biomass and decomposition in stream microcosms. Freshwater Biology, 57, 2504-2513.

Yuen T.K., Hyde K.D. \& Hodgkiss I.J. (1999) Interspecific interactions among tropical and subtropical freshwater fungi. Microbial Ecology, 37, 257-262.

Zar J.H. (1999) Biostatistical Analysis, 4th edn. Prentice-Hall, Englewood Cliffs, NJ. 